\title{
Tertiary Education Trust Fund interventions and sustainable development goals of Olabisi Onabanjo University
}

\author{
Fejoh Johnson ${ }^{1}$, Adesanwo Emmanuel Oloruntoba ${ }^{2}$
}

1 - Institute of Education, Olabisi Onabanjo University, Ago-Iwoye, Ogun State, Nigeria.

2 - Bursary Department, Olabisi Onabanjo University, Ago-Iwoye, Ogun State, Nigeria

Corresponding author contact: femifejoh65@gmail.com

\begin{abstract}
Tertiary Education Trust Fund (TETFUND) was established by Federal Government of Nigeria to tackle the problem of inadequate funding of tertiary institutions which had been a major obstacle to the achievement of sustainable developments in these institutions. This study therefore examined the impact of TETFUND interventions on sustainable development goals (research, academic growth, continuous provision of instructional materials and laboratory equipment) of Olabisi Onabanjo University, Ogun State, Nigeria. Descriptive survey research design was adopted and qualitative data were collected using a questionnaire to elicit information from a total number of 250 respondents from total population of 1,723 staff of the university. From the sample size, 128 (56\%) were males while $122(54 \%)$ were females. Data collected were analyzed using regression analysis to test all the hypotheses at 0.05 level of significance. Findings revealed that TETFUND interventions have significant impact on sustainable development goals of Olabisi Onabanjo University. It is therefore recommended that Federal Government should step up efforts to ensure that tertiary institutions (federal and state owned) are adequately funded through TETFUND and also do more in the area of human resource development for the research and academic growth of these institutions.
\end{abstract}

Keywords: Tertiary Education Trust Fund (TETFUND) interventions, Sustainable development goals (SDGs), Nigeria

\section{Introduction}

Education is widely accepted as a major tool for promoting socio-economic, political and cultural development in Nigeria. Asiyai (2015) sees education as a critical tool through which citizens of any nation acquire the right knowledge, skills, values, attributes and attitudes for peaceful living within the society. Idialu \& Idialu (2012) opine that the challenges confronting higher education in Nigeria include financing and funding the growth of education, management challenges and so on but the challenges dealing worst blow on higher education in Nigeria is underfunding. Nwangu (2005) states that the foundation is weak and frail when education is not well funded and the products of such foundation are weak intellectuals.

When there were few higher institutions in Nigeria, government was saddled with the burden of funding institutions and students' enrollment in Nigeria. This increase has gotten to the point where government openly acknowledged that it can no longer be saddled with the responsibility of funding institutions alone. The issue is not only of funding but sustainability of the existing institutions, quality of education and infrastructures

The challenges posed by global environmental changes and their associated socio-economic problems are persistent problems of unsustainability; they are complex and require urgent action and, mainly, a shift in our predicament. This change is required also within our academic institutions with regard to institutional structures, behavioral patterns and the educational setting. The central role of education in economic development and general increase in national productivity need not be allowed to collapse.

Sustainable development in Nigeria requires the availability of competent and committed human resources. Using education as a tool, the government, hopes to produce manpower that will serve in 
different capacities and contribute positively to the nation's socio-economic and political development. There is no doubt that sustainable economic development cannot be achieved without substantial investment in human capital through education. Oghiagbephan (2015) submits that education creates improved citizens and helps to upgrade the general standard of living in a society.

Education raises peoples' productivity and creativity and promotes technological advances. In addition, it plays vital roles in shaping economic and social progress and improving wealth distribution. Consequently, positive social change is more likely to be connected with the production of qualitative citizenry. The quality of knowledge that higher institutions can generate is important to national competitiveness. Sound education sharpens the minds of the individual and help make the society economically, socially and politically viable.

Countries can achieve sustainable development by improving through training at higher levels, the skills of their human capital. World over, higher level manpower training is always seen as a necessary tool for national development. This may be the reason why Abiodun (2016) submits that "such higher level educational provision enables the citizens to acquire skills and techniques which are channeled into human productivity, creativity, competence, initiative, innovation and inventiveness".

Using education as a tool, the government, hopes to produce manpower that will serve in different capacities and contribute positively to the nation's socio-economic and political development. Specifically, the government intends to gear tertiary education towards high level relevant manpower training, self-reliance, national utility and international understanding (Federal Republic of Nigeria (FRN), 2004). In pursuit of these objectives, institutions of higher learning such as Universities, Polytechnics, Colleges of Education and Mono-technics are established in different parts of the country by the government, private organizations and individuals. These institutions admit, train and graduate students in different fields. The expectation is that, the graduates will work in different sectors of the economy and contribute their quotas towards making Nigeria a developed nation (Adeniran \& Kayode, 2012).

According to Oladeji (2014), sustainable development is that sort of development which satisfies the present needs without endangering the future generations to satisfy their own needs. Whether twin approach or the triple pillars of sustainable development are taken into consideration, there exist a common factor which are economic, political, environmental and social sustainability achievable through rational management of physical, natural and human capital.

Sustainable development, according to Boyi (2013) came to prominence in 1987, when the World Commission on Environment and Development produced a report for the United Nation Called "Our Common Future". It is from that report that sustainable development is derived. Thus, sustainable development cantered on "development" which is to meet the needs of the present generation, without compromising meeting the needs of future generations. This implies therefore that sustainable development is the ability to meet needs in order to live happily in the society as well as plan for the future. Hence, sustainable development is to improve the quality of life, to satisfy the basic life needs and enjoy a better quality of life without compromising the quality of life of future generations.

Sustainable development has become a crucial issue in order to raise awareness, increase motivation, for both individuals and organizations, to develop and implement innovative solutions. Hence, an incredible variety of different contributions were offered from different perspectives. The whole idea behind sustainability lies in nations' ability to develop the education of their citizen. Education for sustainable development has been portrayed as an agent that enables people to develop knowledge, values, and skills in order to engage in activities that will improve the quality of life of the citizenry. Dyer, Selby \& Chalkley (2006) submit that an individual should possess the knowledge, skills, attitudes, and values required for living and working in a sustainable manner. It has been argued that these attributes that form the basis of education for sustainable development could aid academics create a framework to infuse sustainability consistently within the educational institutions.

Education aimed at sustainable development should equip people to understand the connections between environmental, economic, social and political systems. Higher education is regarded as a major catalyst for achieving development, in particular through its traditional missions of teaching, research and community services. This will help people to develop the attitudes, skills, perspectives and knowledge to make informed decisions for the benefit of themselves, others and in the future. 
The National Policy on Education of Nigeria states that the goals of education are building; a united, strong and self-reliant nation, a great and dynamic economy, a just and egalitarian society, a land filled with bright and full opportunities for all citizens and a free and democratic society (Orji, 2012).

\subsection{TETFUND as an intervention agency}

From 1980 and beyond, the decay of all tiers of education was monumental. Facilities had almost collapsed, teachers and lecturers' morale was at its lowest. In 1990 the Federal Government of Nigeria set up a commission to review higher education in Nigeria (the Gray Longe Commission). The mandate was to review the Lord Ashby's Commission of 1959 which held sway in post-independence Nigerian higher education system.

The Longe Commission came up with the idea of funding higher education through taxing of companies operating in Nigeria. The Tertiary Education Trust Fund (TETFUND) was established as an intervention agency under the TETFUND Act - Tertiary Education Trust Fund (Establishment, etc) Act, 2011. This Act repealed and replaced the Education Tax Act Cap E4 Laws of Federation of Nigeria 2004 and Education Tax Fund Act No. 17, 2003 (TETFUND, 2014). It is a government intervention agency which was aimed at providing supplementary supports to all level of public tertiary institutions with the main aim of using funding to restore all the lost objectives of Tertiary Education in Nigeria.

\section{Statement of the problem}

Sustainable higher education has emerged in response to calls for universities to lead society towards a sustainable future and is considered a distinct but interdisciplinary specialization of study and practice within sustainability science and education for sustainable development. The complex nature of sustainability, the task of infusing sustainability within education sector however, has been viewed as a great challenge to achieving sustainable development using higher education.

Beginning from 1980 the Nigerian educational system was down with funding problems. Facilities had almost collapsed, teachers and lecturers' morale was at its lowest ebb due to low budgetary allocation. This has resulted in poor education outcomes especially in Tertiary institutions. Due to the economic recession in the country, the government is increasingly finding it difficult to meet the high cost of funding higher education. This suggests that the tertiary institutions in Nigeria have been underfunded. In order to bridge the funding gap in Nigeria Universities, the government had established Tertiary Education Trust Fund (TETFUND) to rescue the educational system from total collapse but the problem lies on inconsistency in the part of government to release the fund as when due. This has impacted negatively on educational sectors especially the tertiary education. Hence, the researchers examined the impact of TETFUND interventions on sustainable development goals (research and academic growth and continuous provision of instructional materials and laboratory equipment) of Olabisi Onabanjo University, Ago-Iwoye, Nigeria.

\section{Objectives of the study}

The main objective of this study was to examine the impact of TETFUND interventions on sustainable development goals of Olabisi Onabanjo University. Specifically, the study sought to achieve the following objectives:

1 To determine the impact of TETFUND interventions on research and academic growth in Olabisi Onabanjo University.

2 To assess the impact of TETFUND interventions on continuous provision of instructional materials and laboratory equipment in Olabisi Onabanjo University

3 To determine the composite impact of TETFUND interventions on sustainable development in Olabisi Onabanjo University. 


\section{Research Hypotheses}

The following hypotheses were raised to guide the study:

Ho1: TETFUND interventions have no significant impact on research and academic growth in Olabisi Onabanjo University.

Ho2: TETFUND interventions have no significant impact on continuous provision of instructional materials and laboratory equipment in Olabisi Onabanjo University.

Ho3: TETFUND interventions have no significant composite impact on sustainable development in Olabisi Onabanjo University

\section{Methodology}

\subsection{Research design}

For the purpose of this research work, a survey design was adopted. This research made use of quantitative data to elicit information on impact of TETFUND interventions on sustainable development goals.

\subsection{Population}

The population of this study was made up of all the staff of Olabisi Onabanjo University, AgoIwoye, which is 1,723 (540 teaching staff and 1183 non-teaching staff).

\subsection{Sample and sampling technique}

To arrive at the sample size of the respondents used for the data collection, the formula below was employed.

$$
\mathrm{n}=\frac{\mathrm{z}^{2} \mathrm{p} \cdot \mathrm{q}}{\mathrm{d}^{2}}
$$

where $\mathrm{n}$ - the desire sample size;

$\mathrm{z}$ - the standard normal deviate was set at 1.96

$\mathrm{p}$ - the prevalent of TETFUND interventions $=0.10$ (assumption)

$\mathrm{q}=1.0-\mathrm{p}=1-0.90=0.10$

$\mathrm{d}$ - degree of accuracy desired was set at 0.05 .

For this study, p was set at $90 \%$

$$
\begin{aligned}
& \mathrm{n}=\frac{(1.96)^{2}(0.10)(0.90)}{(0.05)^{2}} \\
& \mathrm{n}=258
\end{aligned}
$$

\subsection{Research instruments}

A secondary data was used as a means for data collection to examine the rate at which TETFUND interventions were released to the institution between 2010 and 2015. The use of secondary data was to ensure that data collected is easy to analyse through the Statistical Packages for Social Sciences (SPSS). Primary data was also used to elicit response from the respondents. The questionnaire was designed to elicit background information. It contained 20 items: these items were carefully framed with a view to eliciting useful information from 258 respondents. The questionnaire was divided into three parts. The section A requested for the demographic data of the respondents e.g sex, age group, qualification, occupation, years of experience that made provision for demographic variables of the respondents. The second part requested for information on sustainable development goals.

\subsection{Method of data analysis}

The statistical analysis used was Regression analysis at 0.05 level of significance. 


\section{Results}

\subsection{Hypothesis one}

Ho1: There is no significant impact of TETFUND interventions on research and academic growth in Olabisi Onabanjo University.

Table 1. Summary of the linear regression analyses of TETFUND interventions on research and academic growth

\begin{tabular}{|l|l|c|c|c|c|c|}
\hline $\begin{array}{l}\text { R= } \mathbf{6 4 7} \\
\text { R-Square }=. \mathbf{4 1 8} \\
\text { Adjusted R-Square }=. \mathbf{3 7 6} \\
\text { Standard Error = 10206.896 }\end{array}$ \\
\hline Source & Sum of Squares & Df & Mean Squares & F & Sig & Remarks \\
\cline { 2 - 7 } & 10416.655 & 1 & 10415.555 & 41.50 & $.037^{\mathrm{b}}$ & Reject $\mathrm{H}_{0}$ \\
\cline { 2 - 7 } Regression & 41666.344 & 4 & 10416.625 & & & \\
\cline { 2 - 7 } Residual & 520833.100 & & & & & \\
Total & 5 & & & & \\
\hline
\end{tabular}

a. Predictor: TETFUND interventions

b. Dependent Variable: Research and academic growth

The result in Table 1 indicated that TETFUND interventions had a significant impact on research and academic growth in Olabisi Onabanjo University $\left(\mathrm{R}=.647 ; \mathrm{R}^{2}=.418 ; \mathrm{F}_{(1,4)}=41.50 ; \mathrm{P}<.05\right)$. This showed that TETFUND intervention accounted for $41.8 \%$ of the total variance in research and academic growth in Olabisi Onabanjo University. The null hypothesis which stated that there is no significant impact of TETFUND intervention on research and academic growth in the Olabisi Onabanjo University was hereby rejected. This result showed that TETFUND interventions had a significant impact on research and academic growth in Olabisi Onabanjo University.

\subsection{Hypothesis two}

Ho2: There is no significant impact of TETFUND on continuous provision of instructional material and laboratory equipment.

Table 2. Summary of the linear regression analyses of TETFUND interventions on instructional material and laboratory equipment

\begin{tabular}{|c|c|c|c|c|c|c|}
\hline \multicolumn{7}{|c|}{$\begin{array}{l}\mathrm{R}=.573^{\mathrm{a}} \\
\mathrm{R}-\text { Square }=. \mathbf{3 2 8} \\
\text { Adjusted R-Square = .257 } \\
\text { Standard Error }=\mathbf{3 5 7 0 7 . 9 5 1}\end{array}$} \\
\hline Source & Sum of Squares & Df & Mean Squares & $\mathbf{F}$ & Sig & Remarks \\
\hline \multirow[b]{2}{*}{ Regression } & 41100.592 & 1 & 41102.560 & 36.51 & $.01^{\mathrm{b}}$ & Reject $\mathrm{H}_{0}$ \\
\hline & 50998.274 & 4 & 12749.568 & & & \\
\hline $\begin{array}{c}\text { Residual } \\
\text { Total }\end{array}$ & 55108.333 & 5 & & & & \\
\hline
\end{tabular}

a. Predictor: TETFUND interventions

b. Dependent Variable: Instructional material and laboratory equipment 
The result in Table 2 indicated that TETFUND interventions had a significant impact on continuous provision of instructional material and laboratory equipment in Olabisi Onabanjo University. $(\mathrm{R}=.573$; $\left.\mathrm{R}^{2}=.328 ; \mathrm{F}_{(1,4)}=36.51 ; \mathrm{P}<.05\right)$. This result showed that TETFUND interventions accounted for $32.8 \%$ of the total variance in continuous instructional material and laboratory equipment provision in Olabisi Onabanjo University. The null hypothesis which stated that there is no significant impact of TETFUND interventions on continuous provision of instructional material and laboratory equipment was hereby rejected. This result showed that TETFUND interventions had a significant impact on continuous provision of instructional material and laboratory equipment in Olabisi Onabanjo University.

\subsection{Hypothesis three}

Ho3: There is no significant composite impact of TETFUND intervention on sustainable development goals of the Olabisi Onabanjo University.

Table 3. Summary of regression analysis of TETFUND interventions on sustainable development goals of Olabisi Onabanjo University

\begin{tabular}{|c|c|c|c|c|c|c|}
\hline \multicolumn{7}{|c|}{$\begin{array}{l}\mathrm{R}=.794^{\mathrm{a}} \\
\mathrm{R}-\mathrm{Square}=.630 \\
\text { Adjusted R-Square }=. \mathbf{0 5 5} \\
\text { Standard Error }=\mathbf{3 2 1 8 3 . 9 6 5}\end{array}$} \\
\hline \multirow{3}{*}{$\begin{array}{l}\text { Source } \\
\text { Regression }\end{array}$} & Sum of Squares & Df & Mean Squares & $\mathbf{F}$ & Sig & Remarks \\
\hline & 44083.367 & 1 & 13446.522 & 17.290 & $.031^{\mathrm{b}}$ & Reject $\mathrm{H}_{0}$ \\
\hline & 41667.500 & 4 & 10416.750 & & & \\
\hline $\begin{array}{l}\text { Residual } \\
\text { Total } \\
\end{array}$ & 55108.3333 & 5 & & & & \\
\hline
\end{tabular}

a. Predictor: TETFUND interventions

b. Dependent Variable: Sustainable development goals

The result in Table 3 showed the significant impact of TETFUND interventions on sustainable development goals of Olabisi Onabanjo University $\left(\mathrm{R}=.794 ; \mathrm{R}^{2}=.630 ; \mathrm{F}_{(1,4)}=17.290 ; \mathrm{P}<.05\right)$. This result showed that TETFUND interventions accounted for $63 \%$ of the total variance in sustainable development goals of Olabisi Onabanjo University. The null hypothesis which stated that there is no significant impact of TETFUND on sustainable development goals of Olabisi Onabanjo University was hereby rejected. This result showed that TETFUND intervention had a significant impact on sustainable development goals of Olabisi Onabanjo University.

\section{Discussion of findings}

The above findings confirmed that TETFUND interventions have really accelerated growth and development of infrastructures in Olabisi Onabanjo University, Ago Iwoye. From the result of the test of hypothesis three it was revealed that TETFUND intervention accounted for $63 \%$ of the total variance in sustainable development goals of Olabisi Onabanjo University. The null hypothesis which stated that there is no significant effect of TETFUND intervention on sustainable development goals of Olabisi Onabanjo University was hereby rejected. This result showed that TETFUND intervention had a significant effect on sustainable development goals of Olabisi Onabanjo University.

The findings are also in agreement with Bamiro (2012) and Yakubu (2011) who affirmed that TETFUND interventions have been positive in the area of capacity building through which from 2008 till date some junior academics have been sponsored with TETFUND both abroad and in Nigerian University in various areas spanning Medicine, Law Sciences, Technology, and other discipline.

From the above, it is evident that in no small measure TETFUND has positively impacted Olabisi Onabanjo University in the area of construction of buildings; procurement of library facilities cum 
books and journal; research and training of staff for better performance; provision of cars to facilitates and improve learning; provision of ICT infrastructures and so on since its inception.

\section{Conclusion}

The positive contributions of TETFUND interventions in Olabisi Onabanjo University can be seen through various projects implemented by TETFUND intervention scheme. The university has witnessed massive improvement in the continuous provision of instructional materials, visible research and academic growth, infrastructural developments in the institution. It is on record that most of the major buildings in the university were erected through TETFUND interventions. The University Main Library, Faculty of Administration Building, Senate Building, Faculty of Education Phase 1 and 2 Buildings and a number of Large Lecture Theatres were constructed wholly through TETFUND interventions. This trend is also replicated in most public tertiary institutions across Nigeria. Funding is an important aspect in the sustainable development of any tertiary institution. Through funding TETFUND intervention has significantly reduced the incessant strike actions that bedevil the university academic programmes. Academic calendar is not being disrupted as before which is an indication that the institution is achieving its set sustainable developmental goals. The current development in OOU is a tripartite joint efforts of the private sector, TETFUND interventions and the University internally generated revenue cum state contributions.

The place of education in the development of any nation is very sacrosanct hence the government of Nigeria should not relent in ensuring a steady and adequate funding of tertiary institution in the country which will definitely lead to the research development of our great nation.

The study concludes that though TETFUND has immensely improved Olabisi Onabanjo University in terms of trained/qualified staff, rehabilitation and construction of buildings, laboratory facilities, library books and journals and many more developmental activities since its inception. However, there is still need for improvement in the area of human resources development. Also, the study further revealed that there were bureaucratic bottlenecks in accessing TETFUND as well as unequal allocation of staff training and or conference fund to state institutions and to individual beneficiaries.

\section{Recommendations}

The following recommendations are made based on the above findings and conclusion:

(i) TETFUND should do more in the area of human resources development for the research and academic growth of government owned tertiary institutions in Nigeria.

(ii) Non-Governmental Organizations (NGOs) should participate in the funding of government owned tertiary institutions in Nigeria through assistance in the development of human resources, construction of buildings and laboratories. This will reduce the financial burden on the part of Federal and State governments.

(iii) Bureaucratic bottlenecks connected with TETFUND approved funds should be removed to promote easy access by government owned tertiary institutions.

(iv) TETFUND should discontinue unequal fund allocation formula to tertiary institutions. 


\section{References}

Abiodun, O. (2016). Sustainable infrastructural delivery in Nigerian higher institutions through Tertiary Education Trust Fund interventions: The UNIBEN experience. Retrieved from https://www.researchgate.net/publications

Asiyai, R. I. (2015). Strategies towards effective management of higher education for building a culture of peace in Nigeria. International Journal of Higher Education, 4(2), 127-138. https://doi.org/10.5430/ijhe.v4n2p127

Boyi, A. A. (2013). Education and sustainable national development in Nigeria: Challenges and way forward. International Letters of Social and Humanistic Sciences, 14, 65-72. https://doi.org/10.18052/www.scipress.com/ILSHS.14.65

Bamiro O. A. (2012). Sustainable financing of higher education in Nigeria: Funding models. Paper presented at a 2-day Consultative Policy Dialogue by the Committee of Vice-Chancellors and Trust Africa, a Dakar-Senegal based HE Development Partner.

Dyer, A., Selby, D. \& Chalkley, B. (2006). A centre for excellence in education for sustainable development. Journal of Geography in Higher Education. 30(2), 307-312. https://doi.org/10.1080/03098260600717406

Federal Republic of Nigeria. (2004). National Policy on Education.(4th ed.). Lagos: NERDC Press.

Idialu, J. U., \& Idialu, E. E. (2012). Entity, ownership, educational subsidies and funding of Nigerian tertiary institutions. Current Research Journal of Social Sciences. 4(1)56-61.

Kayode, J., \& Adeniran, R. (2012). Nigerian newspaper coverage of the millennium development goals: the role of the media. Itupale Online Journal of African Studies, 4(1), 1-17

Nwangwu. N. A. (2005). Issues in financing higher education in Nigeria. Nigeria Academy of Education year book, (3rd ed.). Ibadan: XTM Technologies Press.

Oghiagbephan, A. D. (2015). Restructuring educational goals for national and economic goals in Nigeria. IOSR Journal of Research and Methods in Education, 5(4),8-14. https://doi.org/10.9790/7388-05420814

Oladeji, S. I. (2014). Inaugural lecture series 262. Ile-Ife: Obafemi Awolowo University Press.

Orji, K. E. (2012). The political economy of infrastructural development in Nigeria. Lwati: A Journal of Contemporary Research. 9(1), 217-226

Tertiary Education Trust Fund. (2014). Strategic planning workshop for benefiting institutions: information and guide to year 2014 TETFUND interventions. Benin City: TETFUND Desk Office, University of Benin

Yakubu, M. (2011). Opportunities for researchers under the Tertiary Education Trust Fund. Paper presented at a 2-day workshop on writing fundable/bankable research proposal organized by National Office for Technology Acquisition and Promotion (NOTAP) in collaboration with Modibba Adama University of Technology, Yola held at MAUTECH, Yola on 26-27 October 2011. 